\title{
SOCIAL INEQUALITY IN EDUCATION ANALYZED WITHIN VARIOUS THEORETICAL FRAMEWORKS \\ UDC 316.2:37
}

\section{Lela Milošević Radulović, Suzana Marković Krstić}

University of Niš, Faculty of Philosophy, Department of Sociology, Serbia

\begin{abstract}
The expansion of education and the mass inclusion of generations in certain levels of education have not reduced inequality in education. There have still been numerous causes and forms of social inequality, with far-reaching consequences. The consequences of social inequalities in education are very complex and are manifested in the form of reproduction of social inequality, that is, the self-reproduction of social stratification and the reproduction of economic inequality. Scientists working in various fields deal with the clarification of the problems of social inequality in education and everyone can, from their own standpoint, attempt to discover the basic causes of these inequalities so as to overcome them. In paper we have shown four current theoretical approaches to the problem of social inequality in education: the functionalist theory, radical theory, theory of educational capital and theory of cultural deprivation. Every approach from its own standpoint tries to indicate the relationship between the educational system and social structure, as well as the possibility of overcoming certain social inequality. Based on the analysis of the basic tenets of various theoretical approaches to inequality in education conceptualized the initial hypotheses as the foundation for the functioning of the educational system in the future, based on the principles of meritocracy.
\end{abstract}

Key words: inequality in education, the functionalist theory, radical theory, theory of educational capital, theory of cultural deprivation.

\section{INTRODUCTION}

Despite the dominant discourse on equal opportunity in education, during the last few decades there have still been numerous causes and forms of social inequality, with farreaching consequences. The expansion of education and the mass inclusion of generations in certain levels of education have not reduced inequality in education. Research, both carried out the world over and in our country (Hillmert and Jacob 2003; Bowles and Gintis 2002; Mojić 2012, Marković Krstić, 2014) indicates the fact that socio-economic conditions and that class membership of the family and schoolchildren/students still to a great extent determine

Received November 19, 2016 / Accepted January 20, 2017

Corresponding author: Lela Milošević Radulović

University of Niš, Faculty of Philosophy, Cirila i Metodija 2, 18000 Niš, Serbia

E-mail: lela.milošević.radulovic@ filfak.ni.ac.rs 
the educational possibilities of young people, which in turn determines social selection in education. First and foremost, higher levels need to be included in the education process, and only after that can the chances of working-class students increase. The financial status of the family is linked to the cultural-educational status of the family as an environment in which children and the young live and are socialized. Forms of social inequality in education are manifested as inequality at the onset of education, inequality in the breadth of education, inequality when selecting a school/university, inequality in the conditions for education, but also inequality in terms of success at school. Accordingly, the consequences of social inequalities in education are very complex and are manifested in the form of reproduction of social inequality, that is, the self-reproduction of social stratification and the reproduction of economic inequality.

Thus, social inequality in education has been the subject matter of numerous scientific disciplines, especially sociology of education where the efforts of scientists working in various theoretical frameworks to indicate the conditions where socially differentiating factors increasingly influence the educational possibilities of individuals have increased (Marković Krstić \& Milošević Radulović 2016, 21-63). Considering the fact that there is also a pluralism of theoretical standpoints, the paper analyzes the key concepts of several of the most current theoretical approaches: functionalist theory, radical theory, the theory of educational capital and the theory of cultural deprivation with the aim of a deeper scientific understanding and explanations of the causes and consequences, that is, the wider social conditioning of inequality in education.

\section{THEORETICAL APPROACHES TO SOCIAL INEQUALITY IN EDUCATION}

\subsection{The functionalist perspective}

In the theoretical work of the representatives of the functionalist approach (E. Durkheim, T. Parsons, R. Merton, K. Davis, W. Moore) the role of education is viewed in terms of its contribution to the social system. In addition, the influence of numerous psychological factors on the educational success of schoolchildren/students and assuming positions on the social hierarchical ladder are also analyzed.

Durkheim, one of the founders of this approach, considers the basic function of education to be the transfer of social norms and values. According to him, society can continue to exist only if there is enough homogeneity among its members, which is increased through upbringing by instilling in the child's souls beforehand any essentially similar features which are required by communal living. Education ensures a bond between the individual and society and the development of a feeling of connection with a social group. Durkheim considers that education reflects the necessary diversity since it only diversifies and specializes by helping the individual to acquire knowledge and develop certain skills necessary for performing any future professional activities. This function is especially significant in the industrial society with a complex and specialized division of labor. The goal of education is to create and develop within an individual a certain number of physical, intellectual and moral states which are required of him both by political society as a whole and by a special social group (caste, class, family, profession) which it is meant for (Durkheim 1981, 40-41). Durkheim points out that the important task of society is the connection of individuals into a unified whole and the development of social solidarity, that is, understanding that a social community is more important than an individual. School, for 
Durkheim, is a slice of society, that is, it is a model of the social system where the individual prepares for interaction with the members of society as a whole within the social rules.

The functionalist approach to education was significantly enriched by T. Parsons who pointed out that school, following primary socialization in the family, is the most important agent of socialization which prepares the child for its role as an adult. An individual travels from particularist norms and his ascribed status in the family to universalist norms and the achievement of the status in the society of adults (Haralambos \& Holborn 2002, 779). Just like Durkheim, Parsons considers school to be a slice of society which prepares young people for their roles in life based on the fundamental values of society. It is the responsibility of the school to instill in them new values - the value of achievement and the value of equal opportunity. These values have an important function in society, since a developed industrial society requires a highly motivated workforce which strives for success. The application of the principle various rewards for various types of success enables those with a high achievement rate, as well as those with a low one, to consider the system just and correct, since their status was achieved under circumstances which provide everyone with equal opportunity.

The functionalist schools function in accordance with the principles of meritocracy, and status is achieved based on just deserts (values). The same norms are applied to all students, independent of gender, race, family origin or class of the student. Functionalists see inequality in education as the consequence of the differences in intelligence, in the general abilities and motivations of the individual. For the social position of the individual, school (education) plays an important part, and that role consists of selecting the most able and their preparation to take over their respective roles in society, depending on their educational achievements. Parsons considers it justifiable that schools are able to select the most competent, if that selection is based on just and objective criteria. By rewarding a good performance and the adaptation of schoolchildren to moral values, the school prepares the schoolchildren for future "roles" which they will play as adult members of a hierarchical society in which "there are higher and lower professions". In his opinion, society is stratified ("hierarchical") and thus it is quite natural for school to help in the selection of the best, predetermining in this way a future professional division. However, selection should be "just" and should offer everyone "equal opportunity". Social inequality in school results in school selection which was not determined by social origins (Parsons 1959; cited in Fragudaki 1994, 74-75).

From a functionalist standpoint education is the "most suitable method" of distribution of people in accordance with their values - the most able obtain the best rewarded duties (jobs). Schools contribute to the creation of more suitable conditions for upward mobility, if in the educational institutions people are evaluated in accordance with their achievements, independently of their class, race and gender.

Davis and Moore connect the educational system with the system of social stratification and consider education a means of role distribution. Social stratification is a mechanism which ensures that the most talented and most able individuals are distributed to positions which are for society functionally most important. Considering the fact that high rewards are related to these positions, they act as an incentive. Davis says that the system of education is a "polygon for testing abilities, and accordingly, the means of selection for distributing individuals to various statuses in accordance with their abilities" (Haralambos \& Holborn 2002, 780). 
From the standpoint of functionalism, the educational system of industrial countries is considered a significant channel of social mobility. The role of the school in legitimation of inequality is pronounced, as is the need to study the factors of inequality in school. What is pointed out is that a systematic study of the causes of social inequality is needed, especially of those causes which refer to the personal characteristics of schoolchildren, their motivation, difficulties in adjusting to the differences in family environment, so that by improving the educational system, social inequality can also be diminished.

The functionalist belief that schools act in accordance with the principles of meritocracy is questionable, since practice has confirmed that social stratification in part does not enable the school system to objectively evaluate individuals in accordance with their abilities. Which is why the basic drawbacks of this theoretical approach refer to the fact that it does not take into consideration the possibility that the values which are transferred through the educational system can be the values of the ruling class (the minority), and not society as a whole.

\subsection{Radical theory - conflict theory}

During the 1960's in American sociology, attempts to explain data which indicate the unequal success of schoolchildren depending on their social origin were very frequent. These sociological approaches rejected the functionalist tradition of the time and increasingly used concepts such as "class conflict". The cause of unequal success in school and inequality in education in general is found in the capitalist structure of the American society (Fragudaki 1994, 79). A conflict approach to education begins with the view that groups in existing societies have differing interests and that education in modern societies is more useful to some people than others. This approach indicates that inequality in education is in favor of capitalism (the legitimization of inequality) and thus improvements in the educational system are only possible if they are accompanied by wider social changes. Success in education is related to class membership on which the time an individual will spend in the educational system will depend. Higher class membership enables an individual to stay in the system of education for longer periods of time, and to obtain highly paid jobs irrespective of his abilities. Individuals who do not achieve success, and belong to lower classes, mainly blame themselves for their failure, and not the system which is condemning them to fail.

The theoretical tenets behind these views were found by the representatives of this theoretical framework in the work of Marx and Weber, while some were even under the great influence of functionalists, especially Parsons (A. Gouldner, S. Bowles and H. Gintis). The political intent of some theoreticians is clearly indicated in the titles of their work (for example, Schooling in capitalist America by Bowles and Gintis). Bowles and Gintis believe that for an understanding of the functioning of the educational system, an analysis of the production relations is necessary since the educational system reproduces inequality which emerges from the production processes through inequality in success at school. Considering the fact that the cause of success at school is not one's IQ but the class membership of their parents, it is justifiable to ask the question of how it is possible to explain the fact that students with high qualifications have an above-average IQ? Bowles and Gintis indicate that this relation is mostly a "side-effect" of the continuation of education - the longer an individual stays in the educational system, the more he develops his IQ. Thus, the IQ is a consequence of the length of time spent at school, and 
not its cause. They believe that the contribution of the educational system to an individual's economic success can only partly be explained through cognitive development achieved at school (Bowles and Gintis 2002, 1). Schools prepare young people for accepting business practices in the world of adults through the process of socialization, in the sense of enabling an individual to effectively and without question function in the hierarchical structure of a modern corporation. Attention is not focused on the explicit curriculum, and instead on the socialization which is imposed through the structure of education.

Hidden curriculums, which consist of what schoolchildren and students actually learn during their education, and not of the educational goals of the institutions, enables the formation of an obedient work force in the following manner: it helps the development of a servile work force, of non-critical, passive and obedient workers; conducting research in a New York high school (237 higher grade students) they determined that lower grades are connected to creativity and independence, and higher grades with determination, focus and obedience; it encourages the acceptance of hierarchy - schools are organized according to the hierarchical principle of authority and monitoring and thus the students are prepared for the relations they can find at work, where they would have to be subjected to the authority of the managerial staff; school teaches children that they are motivated by rewards, just like the workforce in a capitalist society is motivated by external rewards; the students do not like to go to school, but they are encouraged by the fact that at the end of their education they will be granted a diploma (the promise of a better paid job); course fragmentation during the school day the student moves from course to course, so this aspect of education suits the fragmentation of the workforce (jobs in factories and institutions are divided into very specific tasks which are performed by precisely determined individuals). Bowles and Gintis have shown that the formal parts of the curriculum are suited to the needs of capitalist employers (Haralambos \& Holborn 2002, 787).

In the interpretation of sociologists this theoretical viewpoint on the educational process is considered one of the essential mechanisms of reproduction of class structure. Inequality in education not only stems from the social context, but also has a fundamental social function, and not only does it spring from social inequality but also reproduces the class structure of society (Bowles and Gintis 1976, 53-147; cited according to Fragudaki 1994, 82). The radical interpretation places educational phenomena into a wider social framework, considering school one of the basic social institutions.

Unlike the theoreticians of the functionalist orientation, the representatives of the conflict theoretical approach question the standpoint that the educational system functions according to the criteria of meritocracy principles and offers equal opportunity, as well as the fact that its basic role is the transfer of values and norms which rule all of society, but not the values of the norms of the ruling class. However, the drawbacks of the theory lie only in the fact that it in a mechanistic way reduces inequality in education to the capitalist structure of society and to private ownership of production means. What stems from it is an indirect political conclusion that inequality in education will exist until capitalism exists. The critics of Bowles and Gintis' theoretical framework agree that they have exaggerated the similarities between work and education, but they do not agree with their conclusions that some parts of further development, such as education, are solely shaped by the infrastructure and indicate that schoolchildren and students, still, are not passive recipients of educational content which is found in formal and hidden curricula. 


\subsection{The theory of educational capital}

The beginnings of this theoretical approach can be found in Pierre Bourdieu and JeanClaude Passeron's study The Inheritors: French Students and Their Relation to Culture (1964), and the further development of the problem of cultural reproduction in the work Reproduction: elements of a theory of the education system (1970). This theoretical framework was further developed in the Parisian center for European sociology and offers an original culturological explanation of educational achievements, the role of education in society, and especially the social mechanisms of school inequality.

In this theoretical approach the existence of economic and social barriers is not considered the only cause of inequality in education. The theoreticians of this provenance criticize those sociologists who replace the analysis of the causes of inequality with its condemnation, preventing in this way the understanding of the mechanism of the given reproduction. Bourdieu and Passeron in their interpretation go further than the simple conclusion on the existence of inequality and its condemnation, as well as the conclusion that inequality is the consequence of capitalism. It is their understanding that the important function of the educational system is cultural reproduction, which reproduces the culture of the "ruling classes". They speak of the dominant culture as the cultural capital since it can, through the educational system, be transferred into wealth and power. Cultural capital is not evenly distributed in the class structure and that is the main cause of class differences in educational achievements. Children from ruling classes are at an advantage because they have already acquired certain skills and knowledge during the preschool days. They possess the key to decipher the messages they keep getting at school, they - "possess the code for the message" (Haralambos \& Holborn 2002, 837).

Based on the empirical studies in the field of higher education, Bourdieu and Passeron concluded that social origin determines the success of students and the selection of their specialization. In order to better understand this phenomenon, they introduced the concept of educational privileges which would later be renamed educational capital. Children from privileged classes come to school equipped with the elements of "free education" which is made up of a group of educational resources (knowledge and insight into cultural creativity). These educational resources have direct applicability in school (even though their content is not included in the courses and contents which are delivered in the school). They provide individuals with the general predisposition for learning, make up a single type of practice which is acquired outside of school, and which significantly influences their success at school. Possessing the abilities of interpretation and understanding ideas and cultural creations is not the result of education but of permanent communication with these creations (Fragudaki 1994, 84). So, in addition to social and economic privileges there is also educational capital, as well as certain "attitudes" and certain types of "behavior" towards school and culture, which differ for special social groups and are transferred from generation to generation. These attitudes and behavior towards school and culture in general Bourdieu later called the educational class ethos.

Students of lower classes are not able to directly get to know and communicate with artwork, and instead are forced to indirectly become familiar with it through literature or teachers. The basic precondition for the better success of schoolchildren is free education, and not hard work and a will to succeed (for more details see Fragudaki 1994). Social origin also conditions the "behavior" toward knowledge acquired at school and during education, so that children from privileged families achieve higher success, are more able 
and resourceful. Bourdieu assigns value to style and form, rather than to content and considers the way in which students present themselves and their work to be more important than the content of their work within the curriculum. The more similar a student's style is to that of the ruling classes, the greater his chances for success. Students who come from the working class are discriminated against in two ways: their style differs from the style of the dominant culture and they are not able to understand an entire range of significant items which are built into the "grammar, accent, tone, pronunciation“ of the teachers, since they are expressed in a „civic manner" which differs from the „ordinary means of expression“ characteristic for working-class students (for more information see Haralambos \& Holborn 2002, 837).

According to Bourdieu, the main role of the educational system is the social function of elimination which consists of the elimination of members of the working class from higher educational levels, and is achieved in two different ways: failing at exams and self-elimination (Haralambos \& Holborn 2002, 838). Working-class students have, to a small extent, acquired the dominant culture, so there is a greater probability that they will fail their exams, and this will make it impossible for them to go on to higher levels of education. The privileged position of the ruling class justifies the educational success, and the underprivileged position of the lower classes becomes legitimate, based on the educational failure. Accordingly, Bourdieu concludes that the main role of education is the contribution to social reproduction, reproduction of the relations of power and privilege among the social classes.

With the goal of a scientific understanding of the social role of school, Bourdieu and Passeron introduce the concept of symbolic violence whose theoretical background can be found in the work of Marx and Weber. Symbolic violence is violence which consists of imposing "meaning". Imposing the reproduction of ideas, interpretations, principles, values - "meanings" is done directly through institutions (the school, the church). Each pedagogical act is, objectively speaking, symbolic violence, since it includes the cultural self-willingness of arbitrary authority. In that sense, the selection of meaning is carried out, which makes up a culture and belongs to a certain stratified society. The ruling culture is the culture of the ruling classes, and these classes are at the same time the most highly educated (Bourdieu and Passeron 1977).

In the Bourdieusian theoretical framework there is also the concept of a habitus which refers to the way one lives, the values, proclivities and expectations of certain social groups. Bourdieu considers habitus to be closely connected to the development of taste, and it in turn is closely connected to education and class membership (Bourdieu 1984). In order to explain how these mechanisms function, Bourdieu introduced the concept of the social field which marks a "domain" in society (education, political parties, the media) in which individuals, groups or institutions fight with various strengths and according to certain "rules of the game" which are a part of that domain. The field is an objective domain of social activity which consists of maintaining and practicing developing relations between social positions founded on the relations of power. Social power is capital which should not be equated with economic wealth, since economy is only one of the social fields.

The theoretical approach of Bourdieu and Passeron contributed to a better understanding of the internal mechanisms which function within the educational system, and which enable the reproduction of social inequality through education. Cultural capital, as well as the 
culture of privileged classes (high society status) is often considered an important mechanism in reproduction of educational and social hierarchies.

\subsection{The theory of cultural deprivation}

Inequality in education according to the postulates of the theory of cultural deprivation is the result of differences between the sub-cultures the students themselves belong to. Some of the cultural conditions which make it difficult from schoolchildren from poor families to achieve success in school are differences in habits, tastes, attitudes, priorities and language (Hyman, Bernstein, Bourdieu, Willis) (cited according to Gamoran 2001, 143-144).

Based on empirical data, H. H. Hyman noted differences between the systems of value of the working and middle class. The members of the working class did not stake as much on education, tried less to achieve higher status at work, placed more value on security and direct economic gain and rejected risk and investment which are related to higher social status professions. They believe less in the possibility of personal growth, and this conviction is probably the foundation for their assigning lesser importance to education and higher-status professions (Haralambos \& Holborn 2002, 829).

B. Sugarman looked for an explanation in the different attitudes of these classes. In his opinion, many middle-class professions offer the possibility of constant progress and increase in status, which encourages planning for the future, that is, investing time, energy and money in education, while in the case of working-class professions the peak in profit is quickly achieved. Working-class students are socialized in their social framework, which in part can explain the low level of educational achievements. Their characteristics include: fatalism (accepting the state of things instead of striving to fix it which will not lead to success at school); direct satisfaction (enjoying the happiness of the moment, not sacrificing it for a future reward, it encourages early completion of education due to obtaining direct rewards - a paycheck, freedom); orientation towards the present (could additionally weaken motivation for success in school) and collectivism (loyalty to a group and not emphasizing individual success). In that sense, Sugarman concludes that the students from working-class families are placed in a more unfavorable position due to their class sub-culture (Haralambos \& Holborn 2002, 830).

J. W. B. Douglas studied the differences in educational success among students with similar abilities, but of different social origin. He concluded that middle-class students during the primary socialization get more attention and encouragement from their parents and that this is the foundation for greater educational success. By paying greater individual attention and setting higher norms which need to be met, parents create a motivational climate which suits intellectual development. In addition, it shows that the length of education is connected to the social class the student belongs to, that is, that working class students leave school at an earlier age.

B. Bernstein dealt with the differences in speech patterns, bearing in mind the significance which language has in communication and learning. He distinguishes between two types of speech patterns: developed and a limited system of signs. While the middleclass members use both systems, the members of the working class use the limited system of signs. It is characterized by stenographic speech, identifiable through its short, grammatically simple and incomplete sentences. On the other hand, a developed system of signs explicitly uses words to convey a variety of meanings. It is used to convey 
details, clearly speak of relations and offer explanations. Its meanings are universalistic, and so are not related to a certain context.

The origin of the speech patterns of social classes Bernstein explains through family relations. On the one hand, family life of the working class is favorable for the development of a limited linguistic code, since in the working class family everyone's position is clearly known. Status is clearly identified based on gender, age and family relations. Clarity of status does not require any kind of debate or development in verbal communication. On the other hand, the relations between the middle-class family members is less rigid and less clearly defined, more founded on agreements and debate. For that reason, meaning in verbal communication must be explicit. A limited system of signs by its nature reduced the chances of working-class students to successfully acquire their knowledge and skills which are required by the educational system. Schools nurture the language of the middle class, not taking into consideration the difficulties that those coming from environments marked by social and cultural deprivation are struggling through. Guilt as a result of failure is transferred onto the child, its family, its immediate environment and sub-culture. Its environment is not just poor in an economic, but also a cultural respect (Haralambos \& Holborn 2002, 834). The theory of cultural deprivation is an indication of the inability of achieving the ideal of equal opportunity. Previously it was considered that equal chances exist when everyone has unlimited and free access to all the fields of education, but today it is claimed that equal opportunity exists only when the levels of achievement of all social groups are similar. In that sense, the emphasis has shifted from equality of access to equality of results. From this theoretical perspective, chances can become reality only if they are compensation for deprivation and the shortcomings of groups with lower income. Considering the fact that the greatest damage is done during primary socialization, when the sub-standard culture is acquired in an environment which is deprived of "wealth" and encouragement, compensatory education should take place at the preschool age.

Critics of this theory believe that it hides the true factors which prevent equal opportunity in education, since shifting blame onto the child and its environment distracts attention from the lack of an educational system. Some critics (Morton, and Watson 1973) claim that programs such as compensatory education cannot delete the inequality of opportunity in education, which is founded on social inequality and society as a whole. Compensatory education is only a small attempt to improve the existing system, while a thorough change in the system as a whole is required. Equal opportunity in education can be realized only in a society without social inequality.

\section{CONCLUDING THOUGHTS IN THE CONTEXT OF THE DEMOCRATIZATION OF EDUCATION}

Sociology started analyzing the phenomenon of inequality in education more intensively during the $20^{\text {th }}$ century, and so it was able to formulate several relevant theoretical-methodological approaches to this complex sociological problem. Despite the numerous theoretical and empirical attempts in the past to widely study social inequality in education (their causes, shapes and consequences), in modern society they received their specific characteristics and can still be identified as the focus of scientific interest. Scientists working in various fields deal with the clarification of the problems of social 
inequality in education and everyone can, from his own standpoint, attempt to discover the basic causes of these inequalities so as to overcome them.

In this paper we have shown four current theoretical approaches to the problem of social inequality in education (the functionalist theory, radical theory, theory of educational capital and theory of cultural deprivation). Every approach from its own standpoint tries to indicate the relationship between the educational system and social structure, as well as the possibility of overcoming certain social inequality. Various causes of inequality have been identified in education and educational achievements which mostly rest on the inequality at the start of the education process, and then the differences in the quality of education. The representatives of these theories, through a sociological approach and analysis of the educational system as the sub-system of global society, critically evaluate the existing educational systems by designing new models for their functioning, where in some of them there is special emphasis on the dominant role of participants in the educational process (schoolchildren/students, teachers and parents) from the domain of the realization of equal opportunity in education and for the democratization of education (the theory of cultural capital and cultural deprivation).

Considering the theoretical-methodological standpoint, theoretical interpretations of social inequality in education can be grouped (with a certain deviation) into two: the socioeconomic and sociocultural. According to the first theoretical approach, social inequality in education can be explained through the dominant influence of socioeconomic determinants. The functionalist approach to social inequality in education is based on the premise that social position of an individual should suit his abilities, so that the functioning of the system of education adds not only to the function of socialization, but also to the social-structuring function (which is the basic precondition for designing a model of a meritocratic society), while the radical theory sees the cause of inequality in success at schools and in education in "the clash of class interests" and the capitalist structure of society.

The second theoretical approach, the sociocultural one, considers social inequality in education through the overall influence of social and cultural determinants. Thus, a new theoretical interpretation of social inequality in education was offered by the socioculturological approach to this phenomenon, via the theory of educational capital and the theory of culture deprivation. According to the basic tenets of the theory of educational capital, education is a means of reproducing social inequality, and the school system is "a tool of symbolic violence", which eliminates everyone who does not adapt to its standards. Success in education depends on the previously achieved cultural capital, which is correlated with the symbolic and/or economic. Bourdieu and Passeron in their work break down the myth of school as a neutral institution, independent of social relations, which focuses the students' attention towards a single "universal" culture. Students do not have equal opportunity in school, not because they do not have equal abilities, but because in school, the attitude and habitus which are close to the dominant ones are favorized. However, social conservatism which is manifested in the school system is not evident, and the mechanisms of domination are hidden (the connection between the class and educational culture is not explicit), so that the actors themselves are not aware of them. The different positions of the students are understood as a consequence of inequality in academic achievement, and thus offer legitimacy to those social inequalities from which they originate and those which they reproduce. The educational system is especially effective in maintain the power of the ruling class, even though it is presented as a neutral 
body founded on the principles of meritocracy which offer everyone equal opportunity, it contributes the most to the "reproduction of the established order".

From the perspective of the theory of cultural deprivation, inequality in education is manifested in the form of connections between deprived sub-cultures of certain segments of society and achievements which result from low levels of education. Namely, the lack of success in education of a "culturally deprived child" from sub-culture groups with low incomes is explained not only by the poverty in terms of economy, but culture as well. Among the shortcomings of these children we find language deprivation, a wide range of attitudes, norms and values which are necessary for achievements related to higher education. In that sense, equal opportunity can become a reality if there is compensation for deprivation and the shortcomings of these sub-culture groups (with low income). Then the students from culturally deprived families would have an equal chance to use the possibilities which are being offered for free to all the members of society and they can then achieve success at school. Thus the initial concept of equal access to education, in this theoretical perspective, shifts to creating the preconditions for equality of the educational results of all the members of society.

Based on the analysis of the basic tenets of various theoretical approaches to inequality in education, we can conceptualize the following initial hypotheses as the foundation for the functioning of the educational system in the future, based on the principles of meritocracy:

(1) the key challenge of the educational system is the creation of favorable conditions for the decrease of the influence of factors such as the family and social origin of the schoolchildren/students, which are perceived as obstacles for the equal approach to education (the availability of education);

(2) creating the conditions for different influences of social mechanisms and institutions which would increase the chances of each individual for realizing their potential;

(3) reforms of the educational system enable the initial resources with which the students enter the educational system to affect the output of their educational competencies as little as possible;

(4) the significance of interstate cooperation which is founded on shared experience and measuring progress through mutually agreed upon indicators;

(5) education can be the main channel of social mobility under the condition that equality of opportunity in education includes not only formal equality but also the identification and removal of all social factors which lead to inequality in education and inequality of the educational results;

(6) equal opportunity in education is one of the basic values of today's democratic society.

The incongruity between the education system and the needs of the young is a warning sign that changes in the educational system are necessary in the sense of an increase in educational opportunity, quality of education, as well as an intensification of the process of democratization of education. This means that the educational system is facing great challenges which it will have to react to more quickly, seriously and effectively. 
Acknowledgement: Prepared as a part of the project 179074 Tradition, Modernization and National Identity in Serbia and the Balkans in the Process of European Integration which is implemented by the Centre for Sociological Research, Faculty of Philosophy in Nis and funded by the Ministry of Education and Science of the Republic of Serbia.

\section{REFERENCES}

Bourdieu, P. and J. C. Passeron. Reproduction in Education, Society and Culture. Sage, London, 1977.

Bourdieu, P. Distinction: A Social Critique of the Judgement of Taste. Routledge \& Kegan Paul, London, 1984. Bowles, S. and H. Gintis. "Schooling in Capitalist America Revisited." Sociology of Education 75, 1 (2002): 118.

Dirkem, E. Vaspitanje i sociologija. Beograd: Zavod za udžbenike i nastavna sredstva, 1981.

Fragudaki, A. "Teorije o društvenim nejednakostima u školi." Teme 1-2 (1994).

Gamoran, A. "American Schooling and Educational Inequality: A Forecast for the 21st Century", Sociology of Education. 74, Extra Issue: Current of Thought: Sociology of Education at the Dawn of the 21st Century (2001): 135-153.

Haralambos, M. and M. Holborn. Sociologija: teme i perspektive. Zagreb: Golden Marketing, 2002.

Hillmert, S. and M. Jacob. „Social Inequality in Higher Education. Is Vocational Training a Pathway Leading to or Away from University?“ European Sociological Review 19, 3 (2003): 319-334.

Marković Krstić, Suzana. „Obrazovne aspiracije studentske omladine u Srbiji.“ Kultura 143 (2014): 251-272.

Marković Krstić, S. and L. Milošević Radulović. Humanistička dimenzija obrazovanja mladih u kontekstu savremenih društvenih promena. Niš: Filozofski fakultet u Nišu, 2016.

Morton, D. C. and R. D. Watson. „Compensatory Education and Contemporary Liberalism in the US: A Sociological View." In Equality and City Schools, vol. 2, edited by J. Raynor and J. Harden. London: Routledge \& Kegan Paul, 1973.

Mojić, D. "Obrazovni resursi, orijentacije i delanje mladih". U Mladi - naša sadašnjost. Istraživanje socijalnih biografija mladih u Srbiji, uredila S. Tomanović i dr. Beograd: Institut za sociološka istraživanja Filozofskog fakulteta u Beogradu i „Čigoja štampa“, 2012.

\section{SOCIJALNE NEJEDNAKOSTI U OBRAZOVANJU IZ UGLA RAZLIČITIH TEORIJSKIH PRISTUPA}

Ekspanzija obrazovanja i masovan obuhvat generacija pojedinim stepenima školovanja nisu smanjili nejednakosti u obrazovanju. I dalje su pristuni brojni uzroci i oblici socijalnih nejednakosti sa dalekosežnim posledicama koje su veoma kompleksne, a ispoljavaju se u vidu reprodukcije socijalnih nejednakosti, odnosno samoreprodukcije društvene slojevitosti $i$ u vidu reprodukovanja ekonomskih nejednakosti. Naučnici različite teorijske provenijencije bave se razjašnjenjem problema društvenih nejednakosti u obrazovanju i svako sa svog stanovišta nastoji da razotkrije osnovne uzroke ovih nejednakosti kako bi se omogućilo njihovo prevazilaženje. U radu su prikazana četiri aktuelna teorijska pristupa problemu društvenih nejednakosti u obrazovanju: funkcionalistička teorija, radikalna teorija, teorija obrazovnog kapitala i teorija kulturne deprivacije. Svaki pristup iz svog ugla nastoji da ukaže na odnos obrazovnog sistema $i$ društvene strukture, kao $i$ na mogućnost prevazilaženja određenih društvenih nejednakosti. Na osnovu prikaza osnovnih postavki različitih teorijskih pristupa nejednakostima u obrazovanju koncipirane su neke polazne pretpostavke kao temeljna osnova za funkcionisanje obrazovnog sistema u budućnosti po meritokratskim načelima.

Ključne reči: nejednakosti u obrazovanju, funkcionalistička teorija, radikalna teorija, teorija obrazovnog kapitala, teorija kulturne deprivacije. 